\title{
A mellkassebészeti mütéti teherbíró képesség megítélése, perioperatív légzésrehabilitáció
}

\author{
Vágvölgyi Attila dr. ${ }^{1}$ - Rozgonyi Zsolt dr. ${ }^{2}$ \\ Vadász Pál dr. ${ }^{1,4}$ - Varga János Tamás dr. $^{3}$ \\ Országos Korányi Pulmonológiai Intézet, ${ }^{1}$ Mellkassebészeti Osztály, \\ ${ }^{2}$ Aneszteziológiai és Intenzív Terápiás Osztály, ${ }^{3}$ Légzésrehabilitációs Osztály, Budapest \\ ${ }^{4}$ Semmelweis Egyetem, Általános Orvostudományi Kar, Mellkassebészeti Tanszéki Csoport, Budapest
}

Bevezetés: A mellkassebészeti operabilitást onkológiai, sebésztechnikai szempontok mellett meghatározzák a funkcionális paraméterek. Szükséges a mellkasi mútéti teherbíró képesség és a lehetséges posztoperatív szövődmények megbecslése.

Célkitüzés: A funkcionális operabilitás megítéléséről szóló nemzetközi irodalom és intézetünk gyakorlatának áttekintése.

Módszer: A mellkassebészeti mútéti rizikóbecsléshez szakirodalmi áttekintést végeztünk, előtérbe helyezve a légzésfunkciós, légzésmechanikai, mellkasi kinematikai, terhelés-élettani változókról szóló közleményeket. A légzésrehabilitáció szív-ér rendszeri, izmokra, légzésmechanikára, teljesítőképességre és életminőségre kifejtett hatását vizsgáltuk. Laborparaméterek, társbetegségek, az elhízás, a lesoványodás és a dohányzás rizikóját értékeltük.

Eredmények: A magas vércukorszint, alacsony albuminszint és az emelkedett vesefunkciós értékek növelik a mútéti rizikót. A COPD, alvási apnoe, szívelégtelenség, ischaemiás szívbetegség, obesitas és lesoványodás befolyásolják a műtét kimenetelét. A dohányzásról leszoktatás csökkenheti a posztoperatív szövődményeket. A kontrollált légzési technikák, a mellkasmobilizáció és a tréningprogramok kedvező hatásúak, mindez kiegészíthető pszichoszociális és dietetikai támogatással.

Következtetések: A rizikóbecslést segítő szempontrendszer tartalmazza a légzésfunkció, oxigénfelvétel, laborparaméterek és társbetegségek vizsgálatát. A légzésrehabilitáció kedvező funkcionális hatású, javítva az életminőséget.

Orv Hetil. 2017; 158(50): 1989-1997.

Kulcsszavak: mellkassebészeti mútét, rizikóbecslés, mütéti teherbíró képesség, funkcionális állapotfelmérés, életminőség, perioperatív légzésrehabilitáció

\section{Risk stratification before thoracic surgery, perioperative pulmonary rehabilitation}

Introduction: Besides the oncology and operative surgical technics, functional aspects influence the operability of lung cancer. Preoperative risk stratification, evaluation of postoperative complications needs to be considered.

Aim: To review international literature and experiences of our institute.

Method: We focused the literature of risk stratification of thoracic surgery. Lung function, lung mechanics, chest kinematics, exercise physiology were considered. Effectiveness of pulmonary rehabilitation for cardiovascular system, lung mechanics, muscles, exercise capacity and quality of life were evaluated. Laboratory parameters, comorbidities, obesity, cachexia, smoking cessation were considered.

Results: Elevated blood sugar, kidney function, reduced albumin level increased the risk. COPD, sleep apnoea, heart failure, obesity and cachexia influences the outcome. Smoking cessation may reduce postoperative complications. Controlled breathing technics, chest wall mobilization, training have favourable effects. Psychosocial support and dietetics are important.

Conclusions: Risk stratification is supported by laboratory parameters, lung function, oxygen uptake and comorbidities. Pulmonary rehabilitation can improve functionality and quality of life. 
Keywords: thoracic surgery, risk stratification, surgical endurance, functional state evaluation, quality of life, perioperative pulmonary rehabilitation

Vágvölgyi A, Rozgonyi Zs, Vadász P, Varga JT. [Risk stratification before thoracic surgery, perioperative pulmonary rehabilitation]. Orv Hetil. 2017; 158(50): 1989-1997.

(Beérkezett: 2017. július 25.; elfogadva: 2017. szeptember 28.)

\section{Rövidítések}

ASA $=$ (American Society of Anesthesiologists) Amerikai Aneszteziológus Társaság; $\mathrm{BMI}=$ (body mass index) testtömegindex; BUN = (blood urea nitrogen $)$ karbamid; $\mathrm{CAT}=$ (COPD assessment test) $\mathrm{COPD}$ állapotfelmérő teszt; $\mathrm{CHF}=$ (chronic heart failure) krónikus szívelégtelenség; COPD = (chronic obstructive pulmonary disease) krónikus obstruktív tüdőbetegség; DLCO = (diffusing capacity of the lungs for carbon monoxide) szén-monoxid-diffúziós kapacitás; ERS $=(\mathrm{Eu}-$ ropean Respiratory Society) Európai Tüdőgyógyász Társaság; ESTS $=$ (European Society of Thoracic Surgeons) Európai Mellkassebész Társaság; $\mathrm{FEV}_{1}=$ (forced exspiratory volume in l sec) forszírozott kilégzés első másodpercében kifújt térfogat; $\mathrm{FVC}=$ (forced vital capacity) erőltetett kilégzési vitálkapacitás; IGT = (impaired glucose tolerance) csökkent glükóztolerancia; KS-pipa $=$ kilégzést segítő pipa; $\mathrm{MEF}=($ maximal expiratory flow) kilégzési maximális áramlás; MET $=$ (metabolic equivalent of task) metabolikus ekvivalencia - a nyugalomban mért oxigénszükséglet; $\mathrm{mMRC}=$ (modified Medical Research Council) módosított Medical Research Council dyspnoeskála; $\mathrm{NA}=($ non available $)$ nem elérhető; NSCLC $=($ non small cell lung carcinoma) nem kissejtes tüdőrák; NSQIP = (National Surgical Quality Improvement Program of American College of Surgeons) az Amerikai Sebész Társaság nemzeti sebészi minőségbiztosítási programja; OGTT = (oral glucose tolerance test) orális glükóztolerancia-teszt; OKPI = Országos Korányi Pulmonológiai Intézet; PEP $=$ (positive exspiratory pressure) pozitív kilégzési nyomás; RAMP $=(\mathrm{ramp})$ rámpa - egyenletesen emelkedő teljesítményú protokoll; TGV $=$ (thoracic gas volume) thoracalis (mellkasi) gáztérfogat; $\mathrm{TL}_{\mathrm{CO}}=$ (transfer factor of the lung for carbon monoxide) karbon-monoxidra számított tüdőtranszferfaktor

\section{A posztoperatív pulmonalis komplikációk rizikófaktorai}

A mellkassebészeti mútétek során célunk, hogy minél több beteg minél kisebb kockázattal kerüljön mútétre. A mû́tétek jelentős hányadát tüdőrák miatt végzett beavatkozások teszik ki, azonban meghatározó a benignus folyamatok miatti bevatkozások száma is. Alapvetô fontosságú, hogy az onkológiailag és technikailag operábilis esetek mútétei funkcionális szempontból is elvégezhetőek legyenek. Az utóbbi évek érezhető tendenciája, hogy az időben felismert és operábilis esetek között egyre több az idősebb beteg, akik egyre előrehaladottabb, súlyosabb és több társbetegséggel kerülhetnek mútétre. Ezen betegeknél az általános állapot, gyengébb funkcio- nális paraméterek szignifikánsan javíthatók preoperatív légzésrehabilitációval [1]. A rehabilitáció kedvező hatásait kihasználva olyan betegek is mútétre alkalmas állapotba hozhatók, akik rehabilitáció hiányában aneszteziológiai, kardiológiai vagy általános teherbíró képesség tekintetében relatíve kontraindikáltak lennének. Ezen célok érdekében igyekszünk áttekinteni, hogy egy kockázatmegítélő szempontrendszernek melyek azok a fontosabb elemei, amelyek használatával javulhat a preoperatív kockázatbecslés hatékonysága. A betegeket preoperatíve előkészítve javíthatjuk az általános állapotukat és mútéti teherbíró képességüket, végső soron a páciensek funkcionális tartalékait. Az Országos Korányi Pulmonológiai Intézet (OKPI) Mellkassebészeti Osztályán évente 1100 , altatásban végzett mellkassebészeti mútét történik, szoros együttmúködésben a légzési Intenzív Osztállyal, ahol egy év alatt 1100-1200 beteget látnak el. A 2008 óta múködő önálló Légzésrehabilitációs Osztály évi 6-700 fekvőbeteget kezel. Perioperatív légzésrehabilitációban évente 100 beteg vesz részt. Jelen közleményben a témához kapcsolódó irodalmi adatokat tekintjük át, figyelembe véve az intézet három osztályának szoros együttmúködéséből szerzett tapasztalatokat. Segítséget szeretnénk nyújtani a mellkassebész, tüdőgyógyász, aneszteziológus és rehabilitációval foglalkozó kollégáknak a mellkassebészeti mútét előtti rizikóbecsléshez, körvonalazva azon lehetőségeket, amelyekkel a betegek funkcionális tartalékai, mútéti teherbíró képessége javítható. A légzésrehabilitáció és mellkassebészeti mútétek összefüggéseinek áttekintése a háziorvostól a kardiológuson át mindazon társszakmák mû́velôi számára is hasznos lehet, akik bekapcsolódnak a mellkassebészeti mútét előtti kivizsgálás menetébe.

A mellkassebészeti mútétek posztoperatív szövődményaránya tekintetében is elsődleges szempont, hogy a beteg az elérhető legjobb funkcionális állapotba kerüljön a mútét időpontjára. Ennek egyik lényegi eleme, hogy már ne dohányozzon, amikor mútétre kerül [2-5]. A mucociliaris clearance javítása szempontjából minél hoszszabb dohányzásmentesség elérése a cél. A tüdőfunkció romlása, a súlyos COPD és vele párhuzamban megjelenő cor pulmonale szintén jelentős rizikófaktor a betegek mútétre való alkalmasságát és a posztoperatív szövődményeket tekintve [2-5]. Az elhúzódó mútét, hosszú narkózis és az elhízás szintén komoly, rizikót növeló tényező. A rossz fizikai teljesítőképesség és a fizikai aktivitás alacsony szintje egyértelmúen növeli a rizikót. A mútéti 
rizikó függ a tervezett mütét típusától is. A nehéz, elhúzódó, kiterjesztett mútét és a nagyobb tüdőállományt érintő reszekció magasabb szövődményaránnyal jár. A kiterjesztettebb mútétek fokozott rizikóaránya inkább jelent veszélyt, mint a nagyobb mértékű tüdőreszekciók kapcsán bekövetkező állományvesztés és tüdőfunkcióromlás [2-5].

A tüdőreszekció csökkenti a mútét előtt is beszúkült légzési rezervet, a megmaradó tüdőfunkció a kiindulási légzésfunkció és a tervezett mútét nagyságának függvényében előre kalkulálható. Gondolnunk kell arra, hogy a mütét és a posztoperatív fájdalom következtében hipoventiláció léphet fel, így a vérgázparaméterek nyomon követése rendkívül fontos. A rossz vérgázértékek általános hatásain túl negatívan hatnak a mütéti terület gyógyulására, valamint a beteg posztoperatív pszichés állapotát is jelentősen rossz irányba tudja befolyásolni [4-7]. A köpetretenció légzési elégtelenséghez vezethet, a váladékpangás pedig fokozza a posztoperatív pulmonalis infekciók esélyét [7].

\section{Módszer}

Jelen összefoglalóban szakirodalmi áttekintést szeretnénk nyújtani, hivatkozva saját eredményeinkre is. $\mathrm{Az}$ áttekintett cikkek beválasztási kritériumai a következők voltak:

- a perioperatív időszak légzésrehabilitációjának eredményeit vizsgáló közlemények,

- a sebészeten belül a mellkassebészeti mútétekre vonatkozó cikkek,

- a jelentős betegszámot felölelő közlemények előnyt élveztek,

- a mútéti rizikótényezóket vizsgáló közlemények,

- az életminőségnek a légzésrehabilitációval és mütéttel kapcsolatos változásait elemző vizsgálatok,

- homogén betegcsoportokat tartalmazó vizsgálatok,

- előnyt jelentett a kiválasztásban, ha COPD szerepelt társbetegségként,

- a mellkasi fizikoterápiával és a tüdőgyógyászati rehabilitáció összehasonlításával foglalkozó közlemények,

- előnyben részesítettük a szakmai szervezetek nemzetközi közös állásfoglalásait.

Kizárási kritériumok:

- a kizárólag hasi sebészeti műtétekre vonatkozó vizsgálatok,

- a kis esetszámokról beszámoló közlemények,

- nem homogén betegcsoportokra vonatkozó vizsgálatok.

\section{Kockázati tényezőket felmérő indexek}

A klinikusok három évtizede használnak preoperatív kardiális indexeket, azonban a kis számú validált kohorszvizsgálat miatt a perioperatív tüdőrizikót a tüdőmütétek és más mellkasi mútétek kapcsán nem lehetett eddig megadni. A közelmúltban Johnson és mtsai két indexet fejlesztettek ki az NSQIP 21 paraméter mérése alapján. Egy multifaktoriális posztoperatív légzési elégtelenség indexet hoztak létre. Statisztikai szignifikáns rizikófaktorokat azonosítottak multivariáns analízisben és 180359 nagy érsebészeti és általános sebészeti mütéten áteső beteg kapcsán ezt az indexet validálták egy kohorszvizsgálat során [6]. A légzési elégtelenség definíciójaként a 48 órát meghaladó gépi lélegeztetést vagy nem tervezett intubációt határozták meg. A végleges súlyozott index hét faktort foglalt magában, amelyek között meghatározó volt a beavatkozás típusa. Az indexben szereplő faktorok és pontértékeik a következők: a sebészeti beavatkozás típusa (hasi aortaaneurysma [27 pont], mellkasi [21 pont], idegsebészeti, felső hasi vagy perifériás érmütét [14 pont], nyaki [11 pont]), sürgősségi mütét [11 pont], albuminszint kevesebb mint $30 \mathrm{~g} / 1$ [9 pont], szérumkarbamid magasabb, mint 10,71 mmol/1 (30 mg/dl) [8 pont], részleges vagy teljes ellátásra szorulás [7 pont], krónikus obstruktív tüdőbetegség [6 pont] és életkor (>70 év [6 pont] vagy 60-69 évig [4 pont]) [6]. Magyarországon Pénzes István már a '80-as években saját anyagán kimutatta, hogy a felhasi és mellkasi műtétek során nagyobb a posztoperatív légzőrendszeri szövődmények előfordulása [8].

Johnson és mtsai az előzőekhez hasonlóan posztoperatív pneumonia- és légzési elégtelenség indexet állítottak fel, amely függ az életkorhoz viszonyított relatív testsúlytól, magában foglalja a súlyvesztést, az általános anesztezia típusát és hosszát, a szenzorium érintettségét, előző cerebrovascularis eseményt, négy egységet meghaladó előző transzfúziót, krónikus szteroidhasználatot, egy éven belüli dohányzási anamnézist és napi két pohárnál több alkohol fogyasztását a megelőző két hétben [6].

Ezek az indexek lehetővé teszik a klinikus számára, hogy újraértékelje a magas kockázattal járó sebészeti beavatkozások rizikóját. Az indexek használata segít annak megfogalmazásában, hogy hogyan lehetne csökkenteni a posztoperatív tüdőgyógyászati szövődményeket [6-8].

\section{Diabetes mellitus és a csökkent glükóztolerancia}

A diabetes mellitus és a csökkent glükóztolerancia (IGT) megnöveli a cardiovascularis események kockázatát. A diabeteses betegek többsége 2-es típusú diabetesben szenved, ez romolhat a perioperatív állapotok során. Több klinikai vizsgálat igazolta, hogy a kóros cukoranyagcsere egyértelmüen növeli a posztoperatív szövődmények valószínúségét $[2,7]$.

Klinikai vizsgálatok igazolták, hogy nagy érmútétek során a csökkent glükóztolerancia, diabetes mellitus növeli a szívinfarktus, a troponinemelkedés és a 30 napos szívkomplikációk arányát, és amennyiben a $\mathrm{HbA}_{\mathrm{lc}} 7 \%$ nál magasabb, a várható eredmény rosszabb, mint ha $7 \%$ alatti az érték [2].

Egy másik hasonló klinikai vizsgálat során azt igazolták, hogy az emelkedett glükózszintü betegekben a mor- 
talitási rizikó többszörös a normoglykaemiás páciensek halálozási rizikójához képest. A normoglykaemiás betegekhez viszonyítva négyszeres azon betegek cardiovascularis mortalitása, akiknek a vércukorszintje a diabeteses tartományban van $[2,7]$.

Egy további klinikai vizsgálatban orális glükóztolerancia-tesztet (OGTT) végeztek prospektív formában olyan betegeknél, akik érmütétre vártak és újonnan diagnosztizált diabetes mellitusban szenvedtek vagy glükóztoleranciájuk csökkent. A betegek 25,7\%-ának volt diabetes mellitusa. A csökkent glükóztoleranciában szenvedő betegeknél magasabb volt a szívizom-ischaemia, szívinfarktus és a halálozás aránya, szemben a normális vércukorszinttel rendelkezőkkel $[2,7]$.

\section{Elhízás}

A mellkassebészeti műtét utáni tüdőgyógyászati komplikációk fő oka nem csupán a csökkent tüdővolumen, hanem az általános műtéti kockázat, amely a beavatkozás típusával, kiterjesztettségével is arányos [2-8]. Az elhízás restriktív pulmonalis fiziológiához vezet, tovább csökkenhetnek a tüdőtérfogatok és a mély légvételre való képesség, csökken a funkcionális residualis kapacitás, növekszik a söntkeringés és a hypoxaemia-hajlam. Mindezek következtében növekszik a posztoperatív szövődmények száma [8]. A tüdőgyógyászati komplikációkra vonatkozó klinikai vizsgálatok ugyan sok szempontból jelzik a szövődmények növekedését, de érdekes módon a kemény végpontokban nem találtak jelentősen fokozott mưtét utáni kockázatot, még kóros elhízás esetén sem (1. obesitasparadoxon) [8].

\section{Dohányzás}

Öt multivariációs klinikai vizsgálat (három jó minőségű és két gyenge minőségű) egyértelműen bizonyította, hogy a dohányzás növeli a posztoperatív komplikációs rátát. Klinikai adatok alátámasztják a posztoperatív komplikációs ráta mérsékelt növekedését dohányzási anamnézissel rendelkező betegeknél [7]. Legalább két hónapos preoperatív dohányzáselhagyási időtartam szükséges ahhoz, hogy az intraoperatív váladéktermelődés mennyisége a nemdohányzók szintjére essen vissza [7]. Vannak klinikai adatok azzal kapcsolatosan is, hogy a preoperatív dohányzásleszoktatás nem csökkenti a posztoperatív komplikációk arányát $[9,10]$.

\section{Az Amerikai Aneszteziológus Társaság (ASA) klasszifikációja}

Az ASA klasszifikációját használják világszerte a betegek általános mütét előtti állapotának felmérésére. Cél a perioperatív mortalitás lehetőség szerinti előrejelzése, de használata a posztoperatív tüdőgyógyászati és kardioló- giai komplikációk megítélését is elősegíti. Az öt ASAklasszifikáció a következő:

- egészséges páciens (I. osztály) (jó fizikai terhelhetőség),

- a betegnek enyhe szisztémás betegsége van (II. osztály) (életvitel nem korlátozott),

- jelentősebb (nem közvetlenül életveszélyes) szisztémás betegséggel rendelkező beteg, aki kisebb terhelhetőség mellett kompenzált állapotban van (III. osztály) (életvitel korlátozott),

- dekompenzált szisztémás betegséggel rendelkező beteg, folyamatos életveszélyben/végstádiumú társbetegség (IV. osztály) (életvitel jelentősen korlátozott),

- moribund állapotban lévő beteg, aki várhatóan nem éli meg a 24 órát mútéttel vagy a nélkül (V. osztály) [7].

\section{Obstruktív alvási apnoe}

Az obstruktív alvási apnoe növeli annak a rizikóját, hogy a beteg a közvetlen posztoperatív időszakban valamilyen légúti ellátást igényel, de az egyéb posztoperatív komplikációkra kifejtett hatása nem kellően ismert [7].

\section{A mütét időtartama}

Elhúzódó időtartamúnak a 2,5-3 óránál hosszabb mütétek tekinthetők. Az ezzel kapcsolatos eddigi közlemények nem teljesen evidensek, de abban egybehangzóak, hogy a hosszabb mútétek egyértelmúen nagyobb kockázattal járnak [7].

\section{Szérum vesefunkció mérése}

Két klinikai vizsgálat használta az NSQIP-adatokat a szérumkarbamid-meghatározáshoz. Egy multivariáns analízisben a 7,5 mmol/l vagy magasabb $(21 \mathrm{mg} / \mathrm{dl})$ érték statisztikailag jelentős prediktor faktornak mutatkozott [2]. A rizikó a vér karbamidszintjének emelkedésével fokozódik. Egy klinikai vizsgálat a szérumkreatinin-szint >133 umol/1 (>1,5 mg/dl) értékét rizikófaktorként értékeli multivariációs analízisben [2].

\section{Szérumalbuminszint mérése}

Négy klinikai vizsgálat $(\mathrm{n}=56050)$ univariációs analízise azt igazolta, hogy a posztoperatív pulmonalis komplikációk tekintetében a $35 \mathrm{~g} / \mathrm{l}$ határérték alatti albuminkoncentráció alacsony albuminszintnek felel meg [2]. A várható posztoperatív pulmonalis komplikációs ráta az alacsony és normális albuminszint mellett $27,6 \%$, illetve $7,0 \%$. Bebizonyosodott, hogy az alacsony albuminszint a posztoperatív komplikációk prediktív faktora. Az öt vizsgálatból négyben az albuminszint független rizikófaktornak számít a posztoperatív komplikációk tekintetében. (Az alacsony szint határértéke $30 \mathrm{~g} / 1$ és $39 \mathrm{~g} / \mathrm{l}$ között változik [2].) 


\section{Betegfüggó rizikófaktorok}

\section{Pulmonalis rizikó indexek}

A korábban már említettekhez hasonló indexet használnak a posztoperatív pneumoniás rizikó megítélésére is, amely tartalmazza a magasabb életkort, a súlyvesztést, az általános anesztéziát, a szenzorium érintettségét, az anamnézisben szereplő cerebrovascularis inzultust, a négy egységet meghaladó transzfúziót, a sürgősségi sebészeti beavatkozást, a krónikus szteroidhasználatot, az egy éven belüli dohányzási anamnézist és a megelőző két hétben napi két pohárnál több alkohol fogyasztását (1. és 2. táblázat) [2]. Az ajánlások erősségeit a 3. táblázat tartalmazza.

\section{Klinikai állásfoglalás a rizikóbecslésre vonatkozóan a mellkassebészeti mütétek elött}

A posztoperatív tüdőgyógyászati komplikációk gyakoriak és a perioperatív morbiditás szempontjából fontosak. Egy szisztémás áttekintés adatait közöljük, ami a preoperatív rizikóbecslésre vonatkozik a posztoperatív tüdőgyógyászati komplikációk vonatkozásában nem kardiális mellkassebészeti mütétek esetén. Az 1. és 2. táblázat az összefoglaló erôsségét mutatja a betegek, a beavatkozások, a laboratóriumi értékek és a posztoperatív komplikációk függvényében. A betegfüggő paraméterek közül erős evidencia van az előrehaladott életkor, ASA II. vagy magasabb osztály és a funkcionális függőség megítélésében [7].

1. táblázat |A mellkasi mútétek rizikófaktorainak erősségi szintjei

\begin{tabular}{lcc}
\hline Rizikófaktor & Erósségi szint & Rizikóarány \\
\hline Elörehaladott életkor & A & $2,09-3,04$ \\
ASA II & A & $2,55-4,87$ \\
Szívelégtelenség & A & 2,93 \\
Funkcionális önellátás hiánya & A & $1,65-2,51$ \\
COPD & A & 1,79 \\
Érintett szenzorium & B & 1,39 \\
Cigarettázás & B & 1,26 \\
Alkoholfüggóség & B & 1,21 \\
Mellkasi fizikális vizsgálat során észlelt & B \\
kóros eltérés & & \\
Diabetes & C & \\
Elhízás & D \\
Asthma bronchiale & D \\
Obstruktív alvási apnoe & I \\
Kortikoszteroidhasználat & I \\
HIV-infekció & I \\
Aritmia & I & \\
\hline
\end{tabular}

ASA = Amerikai Aneszteziológus Társaság; COPD = krónikus obstruktív tüdőbetegség
2. táblázat $\mid$ Rizikófaktorok a posztoperatív szövődményeket figyelembe véve [4]

Simított, becsült kockázati hányados $(95 \%$-os CI $)$

\begin{tabular}{|c|c|}
\hline \multicolumn{2}{|l|}{ Életkor } \\
\hline 50-59 év & $1,50(1,31-1,71)$ \\
\hline 60-69 év & $2,28(1,86-2,80)$ \\
\hline 70-79 év & $3,90(2,70-5,65)$ \\
\hline 80 év vagy több & $5,63(4,63-6,85)$ \\
\hline \multicolumn{2}{|l|}{ ASA-klassszifikáció } \\
\hline II. stádium & $4,87(3,34-7,10)$ \\
\hline III. stádium & $3,12(2,17-4,48)$ \\
\hline Szívelégtelenség & $2,93(1,02-8,43)$ \\
\hline Aritmia & $2,90(1,10-7,50)$ \\
\hline \multicolumn{2}{|l|}{ Funkcionális függőség } \\
\hline Parciális & $1,65(1,36-2,01)$ \\
\hline Totális & $2,51(1,99-3,15)$ \\
\hline $\begin{array}{l}\text { Légzésfunkció alapján COPD } \\
\text { II. stádiumtól }\end{array}$ & $2,36(1,90-2,93)$ \\
\hline Testsúlyvesztés & $1,62(1,17-2,26)$ \\
\hline Komorbiditások & $1,48(1,10-1,97)$ \\
\hline Cigarettázás & $1,40(1,17-1,68)$ \\
\hline Érintett szenzomotorium & $1,39(1,08-1,79)$ \\
\hline Kortikoszteroidhasználat & $1,33(1,12-1,58)$ \\
\hline Alkoholfüggőség & $1,21(1,11-1,32)$ \\
\hline
\end{tabular}

ASA = Amerikai Aneszteziológus Társaság; COPD = krónikus obstruktív tüdőbetegség

3. táblázat |Az ajánlások erősségei

A - Erős ajánlás egy rizikófaktor vagy laboratóriumi eredmény tekintetében.

B - Legalább enyhe erősségű ajánlás egy rizikófaktorra vagy laboratóriumi eredményre.

C - Enyhe erôsségú ajánlás, hogy egy bizonyos faktor nem rizikó faktor, vagy a laboratóriumi eredmény nem jelzi előre a rizikót.

D - Erôs ajánlás, hogy egy bizonyos faktor nem rizikófaktor, vagy a laboratóriumi eredmény nem jelzi előre a rizikót.

I - Nincs bizonyíték arra vonatkozóan, hogy az adott tényezőt rizikófaktornak tekintsük, vagy az eddigi bizonyítékok ellentmondásosak.

\section{Mütéti teherbiró képesség megitélése}

A mútéti teherbíró képesség megítélése régebben csak a $\mathrm{FEV}_{\mathrm{l}}$-értéken alapult, azonban a posztoperatív eredményeket figyelembe véve a nemzetközi orvostársaságok az ERS (Európai Tüdőgyógyász Társaság) és az ESTS (Európai Mellkassebész Társaság) - egy komplex felmérést ajánlanak, amely magában foglal más légzésfunkciós értéket is és a maximális teljesítmény során mért oxigénfelvételi értéket egyaránt [7]. 


\section{Spirometria}

A spirometriás értékekkel kapcsolatban nincs elérhetó klinikai vizsgálat, amely a restriktív tüdőbetegségekkel vagy restriktív fiziológiával foglalkozna a mellkasfali vagy neuromuscularis betegségek tekintetében [7].

Az elérhető klinikai adatok alapján azonban elmondható, hogy a spirometria - rossz mért értékek esetén meghatározza a posztoperatív tüdőgyógyászati komplikációk kialakulásának a magas kockázatát, de az adatok nem egyértelmúek [7].

A spirometria során a posztbronchodilatátor értékeket kell figyelembe vennünk. $\mathrm{A} \mathrm{FEV}_{1}$, az FVC és a légúti obstrukció mértékének meghatározása létfontosságú. Emellett farmakospirometriás teszttel meg kell nézni a légúti funkció reverzibilitását [7]. Légzésfunkciós vizsgálat: $\mathrm{FEV}_{1^{-}}, \mathrm{FEV}_{3^{-}}, \mathrm{FVC}$-meghatározás és GOLD IIIII esetén testpletizmográfia (TLC, TGV, R) ajánlott. Kislégutak megítélése MEF 25-75\%-kal lehetséges [3].

Általánosan elmondható, hogy a $\mathrm{FEV}_{1}>1,5$ liter esetén lobectomia, $\mathrm{FEV}_{1}>2,0$ liter (>80 ref\%) esetén pneumonectomia végezhető.

$\mathrm{Az}$ aneszteziológiai döntés a prediktív posztoperatív (ppo) $\mathrm{FEV}_{\mathrm{l}}$-értéken kell, hogy alapuljon. ppoFEV $\mathrm{F}_{\mathrm{l}}=$ preoperatív $\mathrm{FEV}_{1} \times$ a tüdőreszekció után megmaradó szegmentek száma/19.

A ppoFEV $V_{1}$ és ppoTLC, valamint a lehetséges mútéti rizikó kapcsolatát a 4. táblázat tartalmazza [11].

\section{Diffúziós kapacitás mérése}

A $\mathrm{FEV}_{1}$-érték mellett a diffúziós kapacitás meghatározása a nemzetközi ajánlás szerint is indokolt. A diffúziós kapacitás tekintetében több határértéket javasolnak meghatározni. Például DLCO >60 ref\% esetén: pneumonectomia elvégezhető; DLCO $<60$ ref\%: fokozott kockázatot jelent; míg, ha a DLCO $<40$ ref\%: nem végezhető. Az Európai Tüdőgyógyász Társaság és az Európai Mellkassebész Társaság közös ajánlása lehet mérvadó [12].

\section{Spiroergometriás protokoll - RAMP}

A spiroergometriás vizsgálat során az egyenletesen emelkedő teljesítményú protokoll (RAMP) során meghatározott specifikus oxigénfelvételi érték $\left(\mathrm{VO}_{2} / \mathrm{kg}\right)$ lehet irányadó a mútéti teherbíró képesség megítélésében [7]. A spiroergometriás vizsgálat során mért értékek a szív és tüdő együtttes teljesítményéről adnak képet (5. táblázat). A beteg teljesítóképességét MET-ben is ki lehet fejezni, a kalkuláció alapját a 6. táblázat tartalmazza.

\section{Kardiális preoperatín felmérés}

A kardiális állapotfelmérés ugyanúgy integráns részét képezi a rizikóbecslésnek, mint az előzőekben ismertetett kórállapotok vizsgálata. Figyelembe kell vennünk a cardiovascularis preoperatív rizikófaktorokat, amelyeket a
4. táblázat $\mid \mathrm{A}^{\mathrm{p} p o F E V_{1}}$ és a ppoTL $\mathrm{CO}_{\mathrm{CO}}$ mint szűrési funkció a várható szövődmények vonatkozásában a tüdőreszekciós mútétek előtt

\begin{tabular}{|c|c|}
\hline $\operatorname{ppoFEV}_{1}($ ref $\%)$ & Várható szövődmény \\
\hline$>40$ & Nem vagy kis légúti komplikáció. \\
\hline$<40$ & $\begin{array}{l}\text { A perioperatíve halál vagy cardiopulmonalis } \\
\text { komplikációk megnövekedett rizikója. }\end{array}$ \\
\hline$<30$ & $\begin{array}{l}\text { Posztoperatív ventiláció valószínúleg } \\
\text { szükséges, és tovább növekszik a halál vagy } \\
\text { komplikációk valószínúsége. } \\
\text { Számítani kell nem sebészi ellátás szüksé- } \\
\text { gességére. }\end{array}$ \\
\hline $\operatorname{ppoTL}_{\mathrm{CO}}(\mathrm{ref} \%)$ & Várható szövődmények \\
\hline $\begin{array}{l}>40 \%, \text { ppoFEV }_{1}>40 \% \\
\text { és } \mathrm{O}_{2} \text {-szaturáció }>90 \% \\
\text { szobalevegőn }\end{array}$ & $\begin{array}{l}\text { Közepes rizikó, nem szükséges további } \\
\text { pulmonológiai vizsgálat. }\end{array}$ \\
\hline$<40 \%$ & $\begin{array}{l}\text { Várhatóan magasabb légúti és kardiális } \\
\text { megbetegedés. }\end{array}$ \\
\hline$<40 \% ;$ ppoFEV $_{1}<40 \%$ & Magas kockázat, spiroergometria szükséges. \\
\hline$<30 \%$ & $\begin{array}{l}\text { A beteg várhatóan hypoxiás oxigénpótlás } \\
\text { nélkül. }\end{array}$ \\
\hline
\end{tabular}

ppoFEV $_{1}=$ prediktív posztoperatív forszírozott kilégzés első másodpercében kifújt levegó térfogata; $\mathrm{ppoTL}_{\mathrm{CO}}=$ prediktív posztoperatív szén-monoxidra számított tüdőtranszferfaktor

5. táblázat |A spiroergometriás vizsgálat során regisztrált értékek

\section{Teljesítmény (WR, Watt)}

Oxigénfelvétel, szén-dioxid-leadás

Szívfrekvencia, EKG

Vérnyomás

Percventiláció, légzési minta

Artériás oxigénszaturáció

Végkilégzési parciális $\mathrm{CO}_{2}$-nyomás

Tünetek (Borg-féle nehézlégzésskála és lábfáradás foka)

Artériás $\mathrm{O}_{2}$ és $\mathrm{CO}_{2}$ parciális nyomása

6. táblázat | Funkcionális kapacitás megítélése MET-ben

\begin{tabular}{ll}
\hline l MET & $\begin{array}{l}\text { El tudja magát látni (evés, öltözködés, } \\
\text { toaletthasználat). } \\
\text { A ház körül körbe tud menni. } \\
\text { Sík terepen } 3-5 \mathrm{~km} / \mathrm{h}-\mathrm{s} \text { sebességgel } 100 \\
\text { métert meg tud tenni. }\end{array}$ \\
\hline 4 MET & $\begin{array}{l}\text { Két emeletet fel tud menni, vagy emelke- } \\
\text { dőn fel tud menni. }\end{array}$ \\
\hline Több mint 8-12 MET & $\begin{array}{l}\text { A ház körül nehéz tárgyak emelése vagy } \\
\text { nehéz bútorok mozgatása. }\end{array}$ \\
\hline$>12$ MET sportolói & $\begin{array}{l}\text { Erôs fizikai erót igénylő sportágak űzése: } \\
\text { úszás, tenisz egyes, labdarúgás, kosárlabda } \\
\text { vagy síelés. }\end{array}$ \\
\hline
\end{tabular}

MET = metabolikus egyenérték - mért oxigénszükséglet 
7. táblázat tartalmaz. A meghatározó szívbetegségeket a 8. táblázat tartalmazza. Sok esetben pacemakerrel rendelkezik a beteg, a funkcionális állapot megítéléséhez a 9. táblázatban lévő tevékenységeket kell elvégezni [13].

\section{Preoperatív légzésrehabilitáció}

A mellkassebészeti mútét előtti, preoperatív légzésrehabilitáció hosszát tekintve nincs egységes álláspont. A legtöbb esetben két-három hetes programot ajánlanak. Sa-

\section{7. táblázat | Cardiovascularis preoperatív rizikófaktorok [13]}

Harmadik szívhang, vagy a lábszárödéma megléte jelzi a szívelégtelenséget

Szívinfarktus az elmúlt hat hónapban, három hónapban, hat hétben $\geq 5$ kamrai komplexum/perc a sebészeti beavatkozás előtt

Sinusrhythmustól eltérô ritmus

Életkor $\geq 70$ év

Sürgősségi sebészeti beavatkozás

Jelentős aortastenosis (nyitási terület $<2 \mathrm{~cm}^{2}$ )

Intraperitonealis, intrathoracalis mủtét vagy aortasebészeti beavatkozás

Legyengült általános állapot markerei (például vesediszfunkció, májbetegség, tüdőbetegség, három elektroliteltérés)

\section{8. táblázat |Aktív szívállapotok [13]}

Instabil coronariaszindróma

Akut vagy nem régi myocardialis infarctus

Instabil vagy súlyos angina (kanadai beosztás szerint III. vagy IV.)

Dekompenzált szívelégtelenség

Jelentős aritmiák

Magas szintű atrioventricularis blokk

Tünetet okozó kamrai aritmiák meglévő szívbetegség mellett

Supraventricularis aritmiák nem kontrollált kamrai ritmus mellett

Súlyos billentyúbetegség

\section{9. táblázat | Pacemakerimplantáció esetén szükséges információk [13]}

\section{Meghatározni az eszköz típusát}

Meghatározni a pace-elés módját és/vagy a defibrillátoros algoritmust

Az elsődleges beültetés indikációjának az ismerete

A beültetés pontos idejének az ismerete

Mikor volt az eszköz ellenórizve

A jelenlegi aktív pulzusgenerátor pontos helyének az ismerete

Elem állapota

Újraállítási módra vonatkozó ismeretek

A megfelelő határérték meghatározása ját tapasztalatunk szerint három hét szükséges egy beteg mütétre való felkészítéséhez és az előzőekben említett kedvező hatások eléréséhez $[14,15]$.

\section{Terápiás célok a preoperatív légzésrehabilitáció során}

A mucociliaris clearance javítása a betegek légúti váladékürítésében létfontosságú. Szükség van a légzésmechanika javítására, amely a rekeszizom-funkciót és a mellkas hiperinflációjának csökkentését egyaránt szolgálja. A perifériás myopathia javítása is szükséges, ami az I-es típusú (oxidatív) izomrostoknak a II-es típusú (glikolitikus) izomrostokhoz viszonyított arányának a növelésével valósul meg [14-16]. A metabolikus folyamatokat figyelembe véve a laktátküszöb eltolódása kedvező hatású, mert ennek révén később kerül a beteg anaerob körülmények közé. A vérgázparaméterek nyomon követését, a gázcsere javítását is célul kell kitűzni. A tréning kiváltotta kedvező cardiovascularis választ is ki kell aknáznunk $[8,13]$. Célunk a maximális teljesítóképesség (hatperces sétateszt és elért csúcsteljesítmény), valamint a fizikai aktivitás növelése (ez utóbbi többfajta mérőmódszerrel mérhető, például: kérdőívek, lépésszámlálók, aktivitásmonitorok és portábilis metabolikus rendszer használatával) [14-16].

\section{A preoperatív légzésrehabilitáció elemei}

A sikeres légzésrehabilitáció három fö alappillére a beteg, a rehabilitációt végző szakembergárda, valamint a beteg közvetlen környezete, családja. A rehabilitációs teammunka interdiszciplináris együttmúködést igényel. A kivizsgáló tüdőgyógyász szakorvoson, rehabilitációs szakorvoson, mellkassebészen, aneszteziológuson, onkológuson, gyógytornászon, légzési fizioterapeutákon, nővéreken és szakápolókon túl a csapatmunkába szükség esetén bevonható további szakemberek a dietetikus, pszichológus, pszichiáter, háziorvos, szociális munkás, foglalkoztató terapeuta és azon társszakmák képviselői, akik a beteg előkészítésébe/kivizsgálásába/utógondozásába bekapcsolódnak vagy konzulensként részt vesznek. Az ő aktív együttmúködésükkel vezethető végig a beteg a légzésrehabilitáció folyamatán, ugyanakkor a beteg és környezetének pozitív, a légzésrehabilitáció adta előnyöket ismerő hozzáállása és elfogadó együttmúködése is szükséges a sikerhez.

A fekvőbeteg-intézményben végzett légzésrehabilitációs program időtartama körülbelül három hét. A légzőizom-diszfunkció és légzésmechanika javítására, a mellkasi hiperinfláció csökkentésére, a légzőizom állóképességének növelésére, a csontos-ízületes bordakosár mozgásainak javulására az alkalmazandó eljárások széles tárháza elérhető. A jól ismert kontrollált légzési technikák (csücsörített ajakfékes légzés, rekeszi légzés, a törzs 45 fokos előredöntése) elősegítik a mellkasi hiperinfláció 
csökkentését, a légzésmechanika javítását és a megfelelő légzésritmus elsajátítását [14-16]. A köpetretenció csökkentésére és a mellkasi hiperinfláció javítására kiválóan alkalmas a „shaker” és a „Pulmotrainer” (a gyakorlatból már kivont KS-pipa [Flutter] helyett). A légzőizomerő javítására is több lehetőségünk van. Erőfejlesztő légzőizomtréningre alkalmas a „Spiroball”, „PEP”-maszk vagy a technikailag újdonságnak számító, jelenleg már elérhető „Powerbreath”. Állóképességi légzőizomtréninget képes kivitelezni a „Spirotiger” hyperpnoe melletti izokapniás körülmények biztosításával [16, 17].

A pszichoszociális támogatás a tumoros betegek elökészítésében és a daganatos ellátás minden fázisában nagy segítséget jelent. Egyéni és csoportos foglalkozások keretében is elérhető a pszichológusok támogatása. A csoportos foglalkozás keretében a betegek meg tudják osztani a betegségük során fellépő problémáikat [15].

A mütét előtti felkészítésben a dietetikus segíthet az anyagcsere-betegségek ellátásában (például diabetes mellitus), és sok esetben a túlsúly csökkentése vagy éppen a túlzott soványság mérséklése és egészséges étrend összeállítása lehet a célunk [14].

A tréningprogramokat tekintve az előzőekben említett légzőizomtréning mellett a felső és alsó végtagi tréning is szerepet kap. A felső végtagi tréning során a karergométereket hívhatjuk segítségül, az alsó végtagi tréningeknél pedig a kerékpár, a futószőnyeg és a fekvőkerékpár is színesítheti a képet [14]. A folyamatosan magas intenzitású tréninget a spiroergometriával meghatározott maximális teljesítmény körülbelül 60\%-án érdemes kezdeni, és az időtartamot, valamint a teljesítményt fokozatosan növelve (a Borg-féle nehézlégzés- és kifáradásskálát 7-en tartva) célszerü elérni a maximális teljesítmény $80 \%$-át [14]. A betegek intervallumtréninget is végezhetnek a teljesítmények váltakoztatásával, illetve nyugalmi periódusok beiktatásával. Ezen tréningforma kedvező lehet legyengült funkcionális állapotú és emelkedett pulmonalis nyomással rendelkező betegeknél [14-17].

Egy 208 betegből álló klinikai vizsgálat során a perioperatív rehabilitáció eredményességét saját beteganyagunkon is vizsgáltuk. Három csoportot képeztünk: 68 beteg csak preoperatív, 72 beteg pre- és posztoperatív, valamint 68 beteg kizárólag posztoperatív rehabilitáción vett részt. A preoperatív rehabilitáció során a $\mathrm{FEV}_{1}, \mathrm{FVC}$ értéke, a kéz szorítóereje, a CAT és az mMRC értéke egyaránt szignifikánsan javult [1].

\section{A posztoperatív légzésrehabilitáció elemei}

A mütét utáni légzésrehabilitációs protokoll például inceptív spirometriát, rekeszi légzést, csücsörített ajakfékes légzéssel kiegészített légzőtornát tartalmazhat. A fizioterápia közvetlenül a mưtét után elkezdődhet. A gyógytornász már az intenzív osztályon meglátogatja a beteget és elkezdi a korai mobilizációt, segítve a már mütét előtt megtanult légzőtorna végzését. Az aktív sebészeti keze- lés befejezését követő légzésrehabilitáció során két héten keresztül ajánlott a 15 perces inhalátorkezelés és köptetés, rendszeres hörgőtágító használata, valamint napi 30 perces tréning vagy 5000 lépést meghaladó séta [14]. A posztoperatív szakban legalább négy napig a hörgőtágító belégzése után négy-hat óránként alkalmazott köptetés kedvező eredményt hozhat. Ezen eszköztárat alkalmazó mútét utáni rehabilitáció létjogosultságát jelzi, hogy a preoperatív légzésrehabilitációnál is nagyobb mértékben tudja növelni az operált betegek fizikai aktivitását $[14,17,18]$. Mindezeket saját vizsgálataink is alátámasztják: 208 betegünkról szóló klinikai vizsgálat során a posztoperatív csoportban (68 beteg) is jelentősen javult a rehabilitáció hatására a $\mathrm{FEV}_{1}, \mathrm{FVC}$, a kéz szorítóereje, a CAT és az mMRC értéke [1].

\section{Az operált tüdőrák komplex ellátása során alkalmazandó légzésrehabilitáció}

Limitált eredmény van jelenleg azzal kapcsolatban, hogy a tüdőrák komplex kezelése során, tüdőreszekció, kemoés radioterápia mellett a légzésrehabilitációnak hol lehet a helye [18]. Tüdőrákos betegeknél kimutatott tény, hogy az izomvesztésból és csökkent izomerőből adódó izomgyengeség összefüggésben van a megnövekvő mortalitási értékkel. Az izomtömeg a BMI-vel szemben a túlélés erősebb prediktor faktora lehet. A tüdőrákfüggő izomvesztés különböző mechanizmusok talaján alakulhat ki, például hipermetabolikus státusz, a tumor indukálta citokinek és hormonok szekréciójának direkt hatása és a tumorfüggő fáradtságérzet, amely a tumorterápiával és a csökkent fizikai aktivitással függ össze. 12 hetes kontrollált rehabilitációs programmal az izomvesztést vissza lehetett fordítani [18]. További analízist igényel ezen betegek életminőségének, teljesítőképességének és túlélésének a longitudinális nyomon követése.

\section{Következtetések}

A tüdőrákos betegek nagy része az aktív kezelési fázisban pszichológiai támogatást igényel, ami a hazai gyakorlatban speciális helyeken már az onkológiai kezelések részét képezi. I-III. stádiumú NSCLC-s betegek esetén kimutatták, hogy a depresszió, a kimerültség és a tünetek arányban álltak a betegek fizikai aktivitásával [18]. Mindezek alapján is célunk a fizikai aktivitás növelése. Bízunk abban, hogy jelen összefoglaló használatával a tüdőgyógyászok, aneszteziológusok, mellkassebészek és rehabilitációs szakemberek számára olyan áttekintést tudtunk nyújtani, amely segít a mellkassebészeti mútéten áteső betegek minőségi perioperatív ellátásában.

Anyagi támogatás: A közlemény megírása anyagi támogatásban nem részesült. 
Szerzôi munkamegosztás: V. A., V. J. T., V. P.: Koncepció, tervezés. V. A., R. Zs.: Adminisztratív támogatás. V. A., R. Zs., V. P., V. J. T.: Beteganyag rendelkezésre bocsátása, kezelése. V. A., R. Zs., V. J. T.: Adatgyüjtés. V. J. T., V. A., R. Zs., V. P.: Adatelemzés és interpretáció. V. A., V. J. T., V. P., R. Zs.: A kézirat megírása. A cikk végleges változatát valamennyi szerző elolvasta és jóváhagyta.

Érdekeltségek: A szerzőknek nincsenek érdekeltségeik.

\section{Irodalom}

[1] Vagvolgyi A, Rozgonyi Z, Kerti M, et al. Effectiveness of perioperative pulmonary rehabilitation in thoracic surgery. J Thorac Dis. 2017; 9: 1584-1591.

[2] Kristensen SD, Knuuti J, Saraste A, et al. 2014 ESC/ESA Guide lines on non-cardiac surgery: cardiovascular assessment and management: The Joint Task Force on non-cardiac surgery: cardiovascular assessment and management of the European Society of Cardiology (ESC) and the European Society of Anaesthesiology (ESA). Eur J Anaesthesiol. 2014; 31: 517-573.

[3] Rozgonyi Zs, Pénzes I. Postoperative respiratory failure. In: Molnár Zs, Bede A (eds.) Practice of respiration. [Posztoperatív légzési elégtelenség. In: Molnár Zs, Bede A. (szerk.) A lélegeztetés gyakorlata.] Medicina Könyvkiadó, Budapest, 2015; pp. 447-471. [Hungarian]

[4] Smetana GW, Lawrence VA, Cornell JE. Preoperative pulmonary risk stratification for noncardiothoracic surgery: systematic review for the American College of Physicians. Ann Intern Med. 2006; 144: 581-595.

[5] Dronkers J, Veldman A, Hoberg E, et al. Prevention of pulmonary complications after upper abdominal surgery by preoperative intensive inspiratory muscle training: a randomized controlled pilot study. Clin Rehabil. 2008; 22: 134-142.

[6] Johnson RG, Arozullah AM, Neumayer L, et al. Multivariable predictors of postoperative respiratory failure after general and vascular surgery: results from the patient safety in surgery study. J Am Coll Surg. 2007; 204: 1188-1198.

[7] Rozgonyi Zs. Thoracic surgical anesthesia and perioperative care. In: Csekeő A. (ed.) Thoracic surgery in everyday practice. [Mellkassebészeti anesztézia és perioperatív ellátás. In: Csekeő A. (szerk.) Mellkassebészet a hétköznapi gyakorlatban.] Akadémiai Kiadó, Budapest, 2013; pp. 39-72. [Hungarian]

[8] Pénzes I, Rozgonyi Zs. Anesthesia and intensive therapy of obese patients. In: Bedros JR. (ed.) Clinical obesitology. [Az elhízott betegek aneszteziológiájának és intenzív terápiájának kérdései. In: Bedros JR. (szerk.) Klinikai obezitológia.] Semmelweis Kiadó, Budapest, 2017; pp. 587-620 [Hungarian]

[9] Theadom A, Cropley M. Effects of preoperative smoking cessation on the incidence and risk of intraoperative and postoperative complications in adult smokers: a systematic review. Tob Control 2006; 15: 352-358.

[10] Wong J, Lam DP, Abrishami A, et al. Short-term preoperative smoking cessation and postoperative complications: a systematic review and meta-analysis. Can J Anaesth. 2012; 59: 268-279.

[11] Portch D, McCormick B. Pulmonary function tests and assessment for lung resection. Update in Anesthesia 2012; 28: 13-21

[12] Brunelli A, Charloux A, Bolliger CT, et al., European Respiratory Society and European Society of Thoracic Surgeons joint task force on fitness for radical therapy. ERS/ESTS clinical guidelines on fitness for radical therapy in lung cancer patients (surgery and chemo-radiotherapy). Eur Respir J. 2009; 34: 1741.

[13] Fleisher LA. Cardiac risk stratification for noncardiac surgery: update from the American College of Cardiology/American Heart Association 2007 guidelines. Cleve Clin J Med. 2009; 76(Suppl 4): S9-S15

[14] Vágvölgyi A, Rozgonyi Zs, Fehér Cs, et al. Advantages of perioperative pulmonary rehabilitation in patients underwent thoracic surgery. [A mellkassebészeti mútéten átesett betegek perioperatív légzésrehabilitációjának előnyei.] Rehabilitáció 2016; 26 : 209-210. [Hungarian]

[15] Hodovan Z, Gyimesi Z, Varga J. Psychological assessment in patients with COPD and lung cancer in perioperative pulmonary rehabilitation. Am J Respir Crit Care Med. 2015; 191: A2028.

[16] Mans CM, Reeve JC, Gasparini CA, et al. Postoperative outcomes following preoperative inspiratory muscle training in patients undergoing open cardiothoracic or upper abdominal surgery: protocol for a systematic review. Syst Rev. 2012; 1: 63.

[17] Mans CM, Reeve JC, Elkins MR. Postoperative outcomes following preoperative inspiratory muscle training in patients undergoing cardiothoracic or upper abdominal surgery: a systematic review and meta analysis. Clin Rehabil. 2015; 29 : 426-438.

[18] Cavalheri V, Jenkins S, Cecins N, et al. Exercise training for people following curative intent treatment for non-small cell lung cancer: a randomized controlled trial. Braz J Phys Ther. 2017; 21: $58-68$.

(Varga János Tamás dr., Budapest, Pihenő út 1., 1121 e-mail: varga@koranyi.hu)

\title{
Zalaegerszegi praxis eladó
}

\author{
Zalaegerszeg kertvárosában TEK-el rendelkező, \\ 2700 kártyás praxis teljes informatikai hálózattal eladó. \\ Ár megegyezés szerint. \\ Érdeklődni a következő telefonszámon lehet: +36 303488744
}

